\title{
A Comparative Study of Personal Values of Male and Female Secondary Teachers of Rewari District
}

\author{
Goldy Gupta ${ }^{1 *}$
}

\section{ABSTRACT}

Value makes life worthwhile, education enriches it and society provides circumstances in which one could lead it successfully or whatever it may mean from time to time. Whole educational system revolves around the teachers. Teachers occupy the pivot role. He is at the core of the process who can 'mend or end' the future of the individual, society and nation. But the teachers' thinking, feeling and actions are guided by his personal values. It is a matter of great sorrow that today secondary teachers have proved themselves worthless to great extent. They have not been justifying themselves as they thought to have their educational growth, standard, ideology and other aspects of their personality are embarrassing to the society. What is the mirror of their value pattern, how it can be modified; for it, the researcher took a sample of 100 secondary teachers; out of which 50 male and 50 female secondary teachers. After collecting and analyzing data, it was found that there is significant difference between the personal values of male and female secondary teachers at religious value, social value, democratic value, hedonistic and power value.

Keywords: Value, Teacher, Secondary, Personal Value, Education.

“Bacon took all knowledge to be his province, but such is the extent of knowledge today that there is not time enough in the years of schooling to include it all. Hence we need a criterion to tell not only what knowledge is good but also what knowledge is better and best to save time by establishing priorities.” (Brubacher)

This establishing of priorities to achieve the best necessarily opens up a vast area of comparisons based on pre-decided norms, criteria and procedures in a continuous manner irrespective of local conditions and situations. Life, as such, has been a long pursuit of such norms that may help us compare and judge so as to arrive at goals. To evaluate or to judge with reference to a comparable norm generally referred to as value. Values, therefore, are the roots on which an intellectual, social and moral super-structure of man's activities is raised so as to be tenable and consistent. A value system may vary as to its nature, intent and extent, it remains central to the

\footnotetext{
${ }^{1}$ Assistant Professor, K.L.College of Education,Dohki (Rewari)

*Responding Author

(c) 2016 I G Gupta; licensee IJIP. This is an Open Access Research distributed under the terms of the Creative Commons Attribution License (http://creativecommons.org/licenses/by/2.0), which permits unrestricted use, distribution, and reproduction in any Medium, provided the original work is properly cited.
} 
act of judging. Values are like rails that keep a train on the track and help it move smoothly, quickly and with direction. It brings quality to life. Generally, whatever helps one in achievement of the desired result or satisfy his or her desire and needs, is considered as value. Value is associated with usefulness and status. Therefore, a value system is the end result of experiences, utility and satisfaction, finding its way into consummation of life experiences, needs, goals and beliefs. Our major concern is to identify such values in the context of wellbeing of total system, incorporating existence of animate and inanimate objects on the earth.

Value-system, school programmes and educational values are the manifestation of the aspirations of a people, at a point, at a point of their social and cultural evolution, development and progress. Values make life worthwhile, education enriches it and, society provides circumstances in which one could lead it successfully or whatever it may mean from time to time. There is a strong relationship between education and values.

"All proximate aims of education take their direction from the aim which itself stands imperishable and eternal.” Educational development considers both immediate and long lasting goals and objectives which inversely, build around intrinsic and extrinsic values.

\section{Meaning of Value}

Etymologically, value means quality and makes a thing, concept or individual important, useful and worth going in for. Philosophically, value signifies neither a thing nor an individual, but is a concept, a thought, an underlying idea, which may vary or even differ, from place to place, time to time, which may find fruitful in favourable conditions and environment.

Brubacher: To state one's aim of education is to state his educational values.

Dewey: Value may be connected inherently with liking, yet not with every, but with those which judgement has approved, after examining the relation upon which the object liked depends.

Henderson: Man acts to satisfy his wants. Anything that satisfies a human want becomes value.

Personal Values are the values refer to those values which are desired and cherished by individual irrespective of his/her social relationships. Its meaning is multiple and complex. For example: punctuality, courage and maturity etc.

Value makes life worthwhile, education enriches it and society provides circumstances in which one could lead it successfully or whatever it may mean from time to time. Whole educational system revolves around the teachers. Teachers occupy the pivot role. He is at the core of the process who can 'mend or end' the future of the individual, society and nation. It is a matter of great sorrow that today secondary teachers have proved themselves worthless to great extent. They have not been justifying themselves as they thought to have their educational growth, standard, ideology and other aspects of their personality are embarrassing to the society. What is 
the mirror of their value pattern, how it can be modified, to find out the answers of such questions, the researcher selected the current topic for research work.

\section{Objectives of the Study}

1. To study the personal values of male secondary teachers

2. To study the personal values of female secondary teachers

3. To find the significant difference, if exists, in the personal values of male and female secondary teachers.

\section{Hypothesis}

1. There is no significant difference exists between the personal values of male and female secondary teachers.

\section{Delimitations}

The present study has been delimited with respect to the following terms:

Area: The study has been delimited to Rewari district of Haryana state only

Sample: The study has further been delimited to a sample of 100 secondary teachers of Rewari District in Haryana state selected at random. Secondary teachers are the teachers, who are indulged in the job of teaching secondary classes.

Sex: Both sex were taken into consideration

Tool: P.V.Q. (Personal Value Questionnaire) prepared by Dr.(Mrs.) G.P. Sherry and Prof. R.P. Verma. The study has been delimited to following values:
1. Religion Value
6. Knowledge Value
2. Social Value
7. Hedonistic Value
3. Democratic Value
8. Power Value
4. $\quad$ Aesthetic Value
9. Family Prestige Value
5. Economic Value
10. Health Value

\section{REVIEW OF LITERATURE}

The literature in any field form the foundation upon which all further work will be built. So, the review of related literature is an essential pre-requisite to actual planning and execution of any research project. The findings of earlier experiment encourage the investigator in avoiding duplicity on one hand and in getting benefit from similar studies on the other in respect of methods adopted and devices used in the collection of the data and their organization and interpretation.

REDDY, S.G. and REDDY. 2004. “Life Values: A Study on M.B.A. Students”. Indian Journal of Applied Psychology, Vol. 41, 13-16

\section{MAJOR FINDINGS:}

1. There is no significant difference in mean importance ratings between any of the pairs of value domains.

2. There is significant difference in mean importance ratings between each value domain in first layer and each domain in second layer

3. With the value domain in the first layer having significantly higher importance ratings compared to the value domain in the second layer. 
AGOCHIYA, DEVINDER PAL. 1992.”A Cross-Cultural study of Personality, Values and Altruistic Behaviour of Youth Workers”. Ph.D. Psychology, Punjab University.

\section{MAJOR FINDINGS:}

1. Youth workers scored higher on altruism, and lower on psychoticism, extraversion and neuroticism.

2. Youth workers were lower on theoretical, economic and aesthetic values whereas they were higher on social, political and religious values in comparison with other adults.

3. Country wise comparisons showed significant differences in altruism, extraversion, neuroticism, social desirability, economic values and aesthetic, social, political and religious values, but not in psychoticism

CHAND, S.K. 1992. “A Study of Personal Values of Adolescent Boys and Girls in relation to Socio-economic Status and Academic Achievement “. M.Phil.,Edu., Utkal University.

\section{MAJOR FINDINGS:}

1. There was no significant correlation between socio-economic status and religious, democratic, economic, knowledge, hedonistic, power and family-prestige value. But, there was significant relationship between socio-economic status and social, aesthetic and health value

2. There was no significant correlation between academic achievement and social, democratic, aesthetic, economic, knowledge, family-prestige and health value.

3. Boys and girls did not differ in religious, social, democratic, aesthetic, knowledge, hedonistic, family-prestige and health value: but differ in economic and power value significantly.

\section{METHODOLOGY}

The method to be employed always depends upon the nature of the problem selected and the kind of data required for the solution of it. But, the method selected should be suitable for the problem under investigation and well understood by the researcher.

\section{Method}

The researcher used the Descriptive Survey method in this study. This method is concerned with the present attempts to determine the status of the phenomena under investigation. The term status and survey suggest the gathering of evidence relating to current conditions. Survey research is a method for collecting and analyzing data, obtained from large number of respondents representing a specific population collected through highly structured and detailed questionnaires or interviews. It goes beyond more gathering and tabulating of data. It involves interpretation, comparison, measurement, classification, evaluation and generalization all directed towards a proper understanding and solution of significant educational problems. 


\section{Sample}

Reliable results can be expected only from good sample. In order to be able to generalize the conclusions, a large and a representative sample is a pre-requisite. Random sampling used in this study. For it, the researcher has been selected randomly a sample of 100 secondary teachers i.e. 50 male and 50 female secondary teachers from Rewari (Haryana). Layout of Sample is as under:

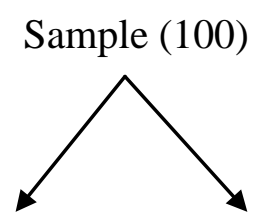

Male Secondary Teachers (50)

Female Secondary Teachers (50)

\section{Tool Used}

P.V.Q. (Personal Value Questionnaire) prepared by Dr. (Mrs.) G.P.Sherry and Prof. R.P. Verma, was used to evaluate the personal values of secondary teachers.

\section{ANALYSIS AND INTERPRETATION OF DATA}

Analysis of data means studying the tabulate material in order to determine inherent factors or meaning. It involves breaking down existing complex factors into simple parts and putting the parts together in new arrangement for the purpose of interpretation. Interpretation calls for a critical examination of the result of one's gathering. To find out the typical performance on each personal value, the researcher calculated Mean, Standard Deviation and applied t-test for measuring the significance of difference.

Table 1, Mean, S.D. and Rank of Male Secondary Teachers

\begin{tabular}{|l|l|l|l|}
\hline VALUES & MEAN & S.D. & RANK \\
\hline Religious & 5.76 & 1.35 & IV \\
\hline Social & 2.40 & 1.37 & X \\
\hline Democratic & 5.24 & 1.62 & V \\
\hline Aesthetic & 6.46 & 1.00 & III \\
\hline Economic & 5.06 & 2.82 & VI \\
\hline Knowledge & 3.80 & 2.56 & IX \\
\hline Hedonistic & 4.96 & 3.12 & VII \\
\hline Power & 7.56 & 5.76 & I \\
\hline Family Prestige & 4.60 & 3.66 & VIII \\
\hline Health & 6.48 & 2.41 & II \\
\hline
\end{tabular}

Table 1 indicates that the highest rank has been achieved by the power value. It shows that male secondary teachers possess characteristics of ruling others and leading others too. They prefer a job where they get opportunity to exercise authority over others. They do not want to busy themselves in social services as they scored lowest at social value. 
Table 2, Mean, S.D. and Rank of Female Secondary Teachers

\begin{tabular}{|l|l|l|l|}
\hline VALUES & MEAN & S.D. & RANK \\
\hline Religious & 3.78 & 1.11 & X \\
\hline Social & 5.70 & 2.19 & V \\
\hline Democratic & 6.84 & 2.21 & II \\
\hline Aesthetic & 5.94 & 3.17 & IV \\
\hline Economic & 4.94 & 2.02 & VII \\
\hline Knowledge & 4.76 & 2.98 & VIII \\
\hline Hedonistic & 8.50 & 2.57 & I \\
\hline Power & 3.82 & 2.27 & IX \\
\hline Family Prestige & 4.98 & 2.46 & VI \\
\hline Health & 5.98 & 2.69 & III \\
\hline
\end{tabular}

Table 2 shows the result of Female secondary teachers. It indicates that female secondary teachers scored highest at hedonistic value. It shows that they have desire for pleasure and avoidance of pain. They give more importance to present than future. They indulge in the pleasures of senses and avoid pain. They do not feel pleasure in going on pilgrimage and do not have faith in God and religious leaders, as they scored lowest at religious value.

Table 3

\begin{tabular}{|l|l|l|l|l|l|l|}
\hline \multirow{2}{*}{ Values } & \multicolumn{2}{l}{$\begin{array}{l}\text { Male } \\
\text { Secondary } \\
\text { Teachers }\end{array}$} & \multicolumn{2}{l|}{$\begin{array}{l}\text { Female } \\
\text { Secondary } \\
\text { Teachers }\end{array}$} & t-value & $\begin{array}{l}\text { Level } \\
\text { Significance }\end{array}$ \\
\cline { 2 - 7 } & Mean & S.D. & Mean & S.D. & & \\
\hline Religious & 5.76 & 1.35 & 3.78 & 1.11 & 8.25 & 0.01 \\
\hline Social & 2.40 & 1.37 & 5.70 & 2.19 & 9.16 & 0.01 \\
\hline Democratic & 5.24 & 1.62 & 6.84 & 2.21 & 4.21 & 0.01 \\
\hline Aesthetic & 6.46 & 1.0 & 5.94 & 3.17 & 1.10 & N.S. \\
\hline Economic & 5.06 & 2.82 & 4.94 & 2.02 & 0.25 & N.S. \\
\hline Knowledge & 3.80 & 2.56 & 4.76 & 2.98 & 1.74 & N.S. \\
\hline Hedonistic & 4.96 & 3.12 & 8.50 & 2.57 & 6.32 & 0.01 \\
\hline Power & 7.56 & 5.76 & 3.82 & 2.27 & 4.29 & 0.01 \\
\hline $\begin{array}{l}\text { Family } \\
\text { Prestige }\end{array}$ & 4.60 & 3.66 & 4.98 & 2.46 & 0.62 & N.S. \\
\hline Health & 6.48 & 2.41 & 5.98 & 2.69 & 1.0 & N.S. \\
\hline
\end{tabular}

Table 3 indicates that male secondary teachers have more religious, aesthetic, economic, power and health value than female secondary teachers. While female secondary teachers have more 
social, democratic, knowledge, hedonistic and family-prestige value as compared to male secondary teachers. There is significant difference between the personal values of male and female secondary teachers at religious value, social value, democratic value, hedonistic and power value. So, null hypothesis is rejected.

\section{FINDINGS}

\section{Personal Values of Male Secondary Teachers}

Male secondary teachers have highest rank of power value and lowest rank at social value. It means they have desirability of ruling others. The lowest rank at social value shows that they have less charity, kindness, love and sympathy. The hierarchical order of their personal values is power value, health value ,aesthetic value, religious value, democratic value, economical value, hedonistic value, family prestige value, knowledge value and social value.

\section{Personal Values of Female Secondary Teachers}

Female secondary teachers have highest rank at hedonistic value and lowest rank at religious value. It indicates that they have desire of pleasure and avoidance of pain. They give more importance to present than future. They indulge in pleasures of senses. The lowest rank indicates that they do not have faith in God and religious leaders. The hierarchical order of their personal values is hedonistic value, democratic value, health value, aesthetic value, social value, familyprestige value, economic value, knowledge value, power value and religious value.

\section{Comparison of Personal Values of Male and Female Secondary Teachers}

It has been found that male secondary teachers have more religious, aesthetic, economic, power and health value than female secondary teachers. While female secondary teachers have more social, democratic, knowledge, hedonistic and family-prestige value as compared to male secondary teachers. There is significant difference between the personal values of male and female secondary teachers at religious value, social value, democratic value, hedonistic and power value.

\section{CONCLUSION}

It is concluded that male secondary teachers possess characteristics of ruling others and leading others. They prefer to rule in a small place rather than serve in a wide place. They are least social, while female secondary teachers give more importance to present than future. They do not have fear of divine wrath and ethics. They indulge in pleasure of senses. It is also concluded that male secondary teachers have more religious, aesthetic, economic, power and health value than female secondary teachers while, female secondary teachers have more social, democratic, knowledge, hedonistic and family prestige value as compared to male secondary teachers. There is significant difference between the personal values of male and female secondary teachers at religious value, social value, democratic value, hedonistic and power value. 


\section{SUGGESTIONS FOR FURTHER RESEARCH}

Seeing the present needs, the researcher feels to suggest the following studies to be undertaken by the next researchers:

1. Similar study can be made for a much larger population to get more generalized conclusions.

2. The study can be conducted on the teachers belonging to rural and urban area.

3. Similar study can be conducted by using some other tool.

4. The study can be conducted further on teachers of government and private schools.

5. The study can be conducted on primary teachers.

\section{EDUCATIONAL IMPLICATIONS}

The result of the study can be usefully employed in educational situation. It has following implications for the teachers and students as under:

1. The study will prove helpful to know the personal values of teachers. A teacher with knowledge of personal values can inculcate and develop good values in students.

2. The study will change the general opinion of the people towards secondary teachers

3. The study will also change the opinion of the general people, who think females are not for job.

4. It will also prove helpful in the selection of the teachers on the basis of personal values.

5. It will also prove helpful in the assignment of various duties at school.

\section{REFERENCES}

Aggarwal, J.C. :Educational Research-An Introduction, New Delhi, Arya Book Depot,1975

Best, John W: Research in Education, New Delhi, Prentice Hall of India Pvt. Limited,1977

Chadha, Satish C.: Educational Values \& Value Education, R. Lall Book Depot, Meerut, 2006

Fifth Survey of educational Survey, 1988-92. Vol II. NCERT

Garrett, Henry E.: Statistics in Psychology and Education, Vakil, Feffer \& Simons Limited,1981

Natraj, Sulabha: Learning to Teach, Charutar Vidya Mandal, Vallabh Vidyanagar, ed 1, Sep. 2006

Sharma, R.A.: Fundamentals of Educational Research, Loyal Book Depot,Meerut,2002

Trivedi, R.N.: Research Methodology, College Book Depot,Jaipur,2005

Yadav H.S. \& Yadav Sudha: Education in Emerging Indian Society, Tondon Publications, Ludhiana, 2006

How to cite this article: G Gupta (2016), A Comparative Study of Personal Values of Male and Female Secondary Teachers of Rewari District, International Journal of Indian Psychology, Volume 3, Issue 3, No. 8, DIP: 18.01.145/20160303, ISBN: 978-1-365-12176-0 